\title{
LIETUVOS IR PASAULIO PLAUKIKŲ PLAUKIMO KRŪTINE JUDESIŲ DERINIMAS IR MOMENTINIO GREIČIO KITIMAS CIKLO METU
}

\author{
Danguolė Satkunskienė, Valentina Skyrienė \\ Lietuvos kūno kultūros akademija, Kaunas, Lietuva
}

\begin{abstract}
Danguolė Satkunskienė. Socialinių mokslų daktarẻ docentė. Lietuvos kūno kultūros akademijos Edukologijos fakulteto dekanė. Mokslinių
\end{abstract} tyrimų kryptis — žmogaus judesių biocheminiai tyrimai, sportininkų technikos veiksmų modeliavimas.

\section{SANTRAUKA}

Tyrimo tikslas - palyginti Lietuvos ir pasaulio plaukiku greičio kitima ciklo metu bei judesiu koordinacijos ypatumus, norint ịvertinti biomechaninius veiksnius, ribojančius Lietuvos plankiku greiti plankiant krūtine. Buvo tiriami keturi Lietuvos nacionalines rinktinès nariai vyrai, kuriu rezultatai plaukiant 50 ir $100 \mathrm{~m}$ krütine siekè atitinkamai 93,3 $\pm 1,6$ ir 92,9 \pm 4,7\% pasaulio rekordo. Gauti rezultatai buvo palyginami su geriausiu Prancüzijos plaukiku (ju 100 m plaukimo krūtine rezultatai - 91,4 $\pm 2,4 \%$ pasaulio rekordo) atitinkamais rodikliais (Chollet et al., 2004).

Sportininkai plauke 25 m ilgio baseine 50 ir 100 m nuotolius varžybiniu greičiu ir $25 \mathrm{~Hz}$ vaizdo kameromis buvo filmuojami virš vandens ir po juo. Nufilmuotas vaizdas apdorotas naudojant SIMI MOTION kompiuterine programa su $50 \mathrm{~Hz}$ vaizdo grotuvu. Tai leido nustatyti plaukiko kūno tašku koordinates, apskaičiuoti momentiní plaukimo greiti ir plaukimo faziu trukme.

Koju ir ranku judesiu koordinacija vertinama laiko intervalais tarp atitinkamu ciklo faziu (Chollet et al., 2004; Leblanc et al., 2005). Išskirtos keturios fazès, kuriu metu rankos ir kojos atlikdavo vienoda veiksma. Šitaip buvo siekiama ¿̇vertinti varomuju jègu veikimo, pasirengimo (ranku tiesimo ir koju lenkimo), slinkimo ir koju glaudimo naudinguma (veiksminguma).

Lietuvos ir Prancūzijos nacionalinès rinktinès nariu plaukimo greičio, tempo ir grybšnio ilgio rodikliai patikimai nesiskyrè. Lietuvos plaukiku didžiausias momentinis greitis pasiekiamas ranku glaudimo pradžioje, Prancūzijos plaukiku — atsispyrimo kojomis pabaigoje. Tai rodo, kad Lietuvos plaukikai ne iki galo išnaudoja koju atsispyrimo jegga, nes šios fazès metu pasiekiamas mažesnis greitis nei užgriebio ir pasitraukimo metu. Ypač neveiksminga atsispyrimo pabaiga, nes greitis pradeda mažèti dar nepasibaigus atsispyrimui. Prancūzijos plaukikai nemaža greičio prieaugi pasiekia ranku glaudimo fazèje, tuo tarpu Lietuvos plaukiku greitis tuo metu mažèja.

Lietuvos plaukikai nepakankamai veiksmingai išnaudoja darbines fazes - atsispyrima kojomis ir ranku glaudima. Pasirengimo fazèse kūnas ilgiau užima neaptakia padètị nei aptakia, dèl to didèja greičio svyravimas ciklo metu.

Raktažodžiai: plaukimas krūtine, greičio kitimas ciklo metu, judesiu derinimas (koordinacija).

\section{IVADAS}

$\mathrm{P}$ laukimas krūtine yra vienas lèčiausių plaukimo būdų, nors rankų ir kojų veiksmai sukuria didelę varomają jègą (Magel, 1970). Šiam plaukimui būdingas didelis greičio svyravimas ciklo metu (Mc Elroy ir Blanksby, 1976; Colman et al., 1998; Silva et al., 2003), kuris atsiranda dèl vandens pasipriešinimo pasirengimo fazejje (rankų tiesimo ir kojų lenkimo). Greičio kitimo kreivių analizè leido nustatyti, kad užgriebio ir atsispyrimo fazių metu greitejjama, o slinkimo, rankų tiesimo ir kojų lenkimo metu letėjama (D'Acquisto et al., 1988; Tourny et al., 1992; Chollet et al., 2004; Leblanc et al., 2007). S. V. Kolmogorovas ir kt. (1997) nustate, kad plaukiant krūtine hidrodinaminis koeficientas 53\% didesnis nei plaukiant krauliu.

Dažniausiai plaukikai, didindami greiti, didina ir plaukimo tempą, mažina grybšnio ilgi trumpindami slinkimo fazę, keisdami judesiu koordinaciją (Sanders, 1996; Chollet et al., 1999; 
Soares et al., 1999). Daugelis autoriu plaukimo krūtine judesių koordinaciją bande įvertinti analizuodami fazių trukmę ir greičio kitimą ciklo metu (Nemessuri, Vaday, 1971; Costill et al., 1987; Craig et al., 1988; D'Acquisto et al., 1988; Tourny et al., 1992; Maglischo, 1993; Vilas-Boas, 1996). D. Chollet ir kt. (2004) tuo tikslu pasiūlè skaičiuoti laiko intervalus tarp rankų ir kojų judesių fazių pradžios.

D. Chollet ir kt. (2004) nustatė, kad rankų ir kojų judesių koordinacija kinta priklausomai nuo plaukimo greičio. Plaukiant lètai $(200 \mathrm{~m}$ nuotolio greičiu) pastovų vidutini plaukimo greiti ciklo metu padeda išlaikyti aptaki kūno padètis slinkimo fazejje: užgriebis atliekamas, kai kojos užima aptakiausią padėti, atsispiriama - kai rankos ir galva yra aptakiausios padèties. Plaukiant greitai padidèja varomąsias jẻgas sukuriančiu fazių santykinè trukmè ir sumažeja slinkimo trukmè, užgriebis atliekamas lenkiant kojas, o atsispyrimas — tiesiant rankas pirmyn.

Judesių koordinacijos tyrimai parodè tam tikrus skirtingo meistriškumo ir lyties plaukiku technikos ypatumus (Leblanc et al., 2005, 2007).

Tyrimo tikslas - palyginti Lietuvos ir pasaulio plaukiku greičio kitimą ciklo metu bei judesiu derinimo ypatumus, norint nustatyti biomechaninius veiksnius, ribojančius Lietuvos plaukiku greiti plaukiant krūtine.

\section{TYRIMO METODAI IR ORGANIZAVIMAS}

Tiriamieji. Tyrimas vyko $2007 \mathrm{~m}$. lapkritigruodi. Buvo tiriami keturi Lietuvos plaukimo rinktinès nariai (amžius 16-21 m.; ūgis 173$193 \mathrm{~cm}$; kūno masè 65 - $84 \mathrm{~kg}$ ) vyrai. Jų rezultatai plaukiant krūtine 50 ir $100 \mathrm{~m}$ nuotolius sieke atitinkamai $93,3 \pm 1,6$ ir $92,9 \pm 4,7 \%$ pasaulio rekordo. Tyrimo rezultatai buvo palyginami su geriausiu Prancūzijos plaukiku (jų $100 \mathrm{~m}$ plaukimo krūtine rezultatai siekè $91,4 \pm 2,4 \%$ pasaulio rekordo) atitinkamais rodikliais (Chollet et al., 2004).

Filmavimas. Plaukikai $25 \mathrm{~Hz}$ vaizdo kameromis buvo filmuojami virš vandens ir po juo. Vaizdas virš vandens registruotas CANON XMI kamera, pastatyta ant baseino krašto, sekant sportininką viso plaukimo metu. Vaizdas po vandeniu registruotas povandeninio filmavimo sistema, važinejjančia ant bėgių, nutiestų baseino pakraščiu. Kamera, nukreipta statmenai i plaukiką, judèjo baseino kraštu ir fiksavo sportininko vaizdą iš šono nuo plaukimo pradžios iki pabaigos.
Prieš startą juodu, vandeniui atspariu žymekliu buvo pažymèti tiriamujų kairès ir dešinès kūno pusès klubo, kelio, čiurnos sąnariai ir viršutinis klubo skiauterès taškai.

Registravimo sistemai sekant sportininka, plaukimo momentiniam greičiui nustatyti būtina turèti nejudanti atskaitos tašką. Tuo tikslu ant baseino skiriamosios juostos kas 5 metrus buvo pakabinti svoriai. Kameros po vandeniu kalibravimui nufilmuotas $2 \mathrm{~m}$ strypas.

Tiriamieji plaukè $25 \mathrm{~m}$ ilgio baseine 50 ir 100 m nuotolius varžybu greičiu startuodami vandenyje (atsispyrus nuo baseino sienelès). Plaukimo laikas buvo registruojamas nuo starto signalo iki plaukimo baigmès (sienelès palietimo rankomis). Poilsis tarp plaukimų truko 10 minučių. Rankiniu laikmačiu buvo registruojama $10 \mathrm{~m}$ plaukimo trukmè kiekviename $25 \mathrm{~m}$ nuotolio tarpe.

Vidutinis plaukimo greitis kiekviename $25 \mathrm{~m}$ nuotolio tarpe buvo apskaičiuotas pagal formulę: $V=S / t_{s}(\mathrm{~m} / \mathrm{s})$ (čia $S=10 \mathrm{~m}, t_{s}-10 \mathrm{~m}$ plaukimo laikas). Plaukiant $50 \mathrm{~m}$ nuotoli vidutinis plaukimo greitis sieke $96,9 \pm 0,67 \%$, plaukiant $100 \mathrm{~m}-93,8 \pm 1,6 \%$ varžybų metu pasiekto vidutinio greičio.

Nufilmuotas vaizdas iš kameros perkeltas i kompiuterị ir apdorotas naudojant SIMI MOTION kompiuterinę programą su $50 \mathrm{~Hz}$ vaizdo grotuvu. Tai leido $20 \mathrm{~ms}$ intervalu nustatyti plaukiko kūno taškų koordinates, apskaičiuoti momentini plaukimo greitị ir plaukimo fazių trukmę.

Plaukimo krūtine ciklo fazès. Visas judesių ciklas (laiko intervalas, per kuri atliekamas visas judesių ciklas - grybšnis rankomis su ikvėpimu ir atsispyrimas kojomis) buvo suskirstytas i penkias rankų ir penkias kojų fazes (Chollet et al., 2004; Leblanc et al., 2005).

Rankujudesiufazès: 1) slinkimas - nuo visiško rankų ištiesimo momento iki plaštakų pasukimo išorẻn; 2) užgriebis ir traukimas - nuo plaštakų pasukimo išorèn iki ju judejjimo išorèn —žemyn — atgal pabaigos (sportininko kūno link); 3) glaudimas - nuo plaštaku judejjimo išorèn—žemyn—atgal pabaigos (sportininko kūno link) iki alkūniu glaudimo ir ju judẻjimo i̇ prieki pradžios; 4) rankų tiesimo pirmyn pirmoji dalis - nuo rankų tiesimo pradžios iki momento, kai alkūnių kampas siekia $90^{\circ}$; 5) rankų tiesimo pirmyn antroji dalis - nuo momento, kai alkūniu kampas yra $90^{\circ}$, iki visiško rankų ištiesimo.

Koju judesiu fazès: 1) atsispyrimas - nuo momento, kai kojos pradeda tiestis, iki visiško jų ištiesimo per kelio sąnari momento; 2) glaudimas - nuo visiško kojų ištiesimo per kelio sąnari 
iki pėdu glaudimo pabaigos momento; 3) slinkimas - nuo maksimalaus pèdų suglaudimo pabaigos iki aktyvaus kojų lenkimo per kelio sąnari pradžios momento; 4) kojų lenkimo pirmoji dalis - nuo aktyvaus kojų lenkimo per kelio sąnarị pradžios iki momento, kai kelio sąnario linkimo kampas yra $90^{\circ}$; 5) kojų lenkimo antroji dalis - nuo momento, kai kelio sąnario linkimo kampas $90^{\circ}$, iki kojų lenkimo pabaigos momento. Kiekvienos fazès trukmè buvo išreikšta procentais nuo viso ciklo trukmès.

Vidutinè ciklo trukmè apskaičiuota pagal formulę: $t_{c}=3 t_{c} / 3(\mathrm{~s})$ (čia $\mathrm{t}_{\mathrm{c}}$ - vieno ciklo trukmé; $3 \mathrm{t}_{\mathrm{c}}$ - trijų ciklu trukmè). Vieno ciklo trukmè nustatyta sumuojant išvardytų fazių trukmę. Grybšnio pradžia buvo laikomas visiško rankų ištiesimo momentas.

Tempas (ciklų dažnumas per laiko vienetą) apskaičiuotas pagal formulę: $T=1 / t_{c} 60$ (c. $/ \mathrm{min}$ ). Ciklo ilgis (atstumas, ivveikiamas vieno grybšnio metu) apskaičiuotas pagal formulę: $L=V / T(\mathrm{~m})$.

Kojų ir rankų judesių derinimas (koordinacija). Kojų ir rankų judesių koordinacija buvo vertinama apskaičiuojant laiko intervalus tarp atitinkamų ciklo fazių, pasiūlytų D. Chollet ir L. Boulesteix (2001) analizuojant plaukimą peteliške ir pritaikytu plaukimui krūtine (Chollet et al., 2004; Leblanc et al., 2005). Apskaičiuoti keturi laiko intervalai, kurie parodo varomosios ir stabdančiosios jègų veikimą. Laiko intervalai tarp kojų ir rankų judesių fazių pradžios ir pabaigos momentu plaukiant krūtine pateikti 1 paveiksle.

Laiko intervalai tarp kojų ir rankų judesių fazių pradžios ir pabaigos momentų: $\mathrm{T} 1_{\mathrm{a}}$ : nuo atsispyrimo kojomis pabaigos iki užgriebio rankomis pradžios; $\mathrm{T} 1_{\mathrm{b}}$ : nuo kojų glaudimo pabaigos iki užgriebio pradžios; T2: nuo kojų lenkimo pradžios ir rankų tiesimo i prieki pradžios; T3: nuo kojų lenkimo pabaigos ir rankų tiesimo i prieki pabaigos; T4: nuo momento, kai kojų lenkimo kampas $90^{\circ}$, iki tol, kai alkūnių kampas siekia $90^{\circ}$.

Šie laiko intervalai buvo išreikšti procentais kojų ciklo trukmès atžvilgiu.
Kojų ir rankų judesių derinimo vertinimas. Rankų ir koju judesių derinimas (koordinacija) buvo vertinami remiantis D. Chollet ir kt. (2004) pateiktu aprašu.

Kai $\mathrm{T} 1_{\mathrm{a}}=0$, atsispyrimo kojomis pabaiga sutampa su rankų užgriebio pradžia. Tai reiškia, kad užgriebis prasideda tada, kai kojos dèl savo padèties sukuria stabdomąsias jègas. Po ištiesimo jos yra žemai ir nesuglaustos. Tai padidina vandens pasipriešinimo jègą.

Kai $\mathrm{T} 1_{\mathrm{a}}>0$, užgriebis rankomis prasideda nepasibaigus atsispyrimui kojomis. Šiuo atveju rankos ir kojos siekia sukurti traukio jègą tuo pačiu metu. Toks plaukimas reikalauja labai daug energijos sąnaudų, nes kojų ir rankų padètis nèra aptaki, plaukiko kūnas sukuria dideles pasipriešinimo jejgas. Taip derinti kojų ir ranku judesius gali tik didelio meistriškumo sportininkai, plaukdami trumpuosius nuotolius. Kai $\mathrm{T} 1_{\mathrm{a}}<0$, užgriebis rankomis prasideda kojas glaudžiant arba kojų slinkimo metu; kai $\mathrm{T} 1_{\mathrm{b}}=0$, užgriebis prasideda po atsispyrimo glaudžiant kojas; kai $\mathrm{T} 1_{\mathrm{b}}>0$, rankų ir kojų judesių derinimas atitinka $\mathrm{T} 1_{\mathrm{a}}>0$ arba $\mathrm{T} 1_{\mathrm{a}}<0$ atveji; kai $\mathrm{T} 1_{\mathrm{b}}<0$, tuo pačiu metu vyksta ranku ir kojų slinkimo fazès; kai T2 ir T3 $=0$, kojos lenkiamos rankų tiesimo metu.

Kai T2 ir T3 $<0$ - neigiamas laiko intervalas: rankos atlieka veiksmą, sukuriantį traukio jègą, koju veiksmai - stabdo judejjimą pirmyn, ir atvirkščiai. Akivaizdu, kad kojų lenkimas ar rankų tiesimas stabdo plaukiką, nors tuo pačiu metu atitinkamai rankos ar kojos atlieka veiksmus, stumiančius plaukiką pirmyn. Toks judesių derinimas nèra veiksmingas, tačiau didelio meistriškumo plaukikai taip plaukdami geba išlaikyti dideli plaukimo greitị.

Kai T2 ir T3 $>0$ - teigiamas laiko intervalas, rankos tiesiamos, kojos užima aptakią padèti slinkimo fazès metu, ir atvirkščiai.

Kai T4 =0, tuo pačiu laiko momentu kojų lenkimo ir rankų tiesimo kampas lygus $90^{\circ}$.

Fazių naudingumo (veiksmingumo) įvertinimas. Buvo išskirtos keturios fazès, kurių metu

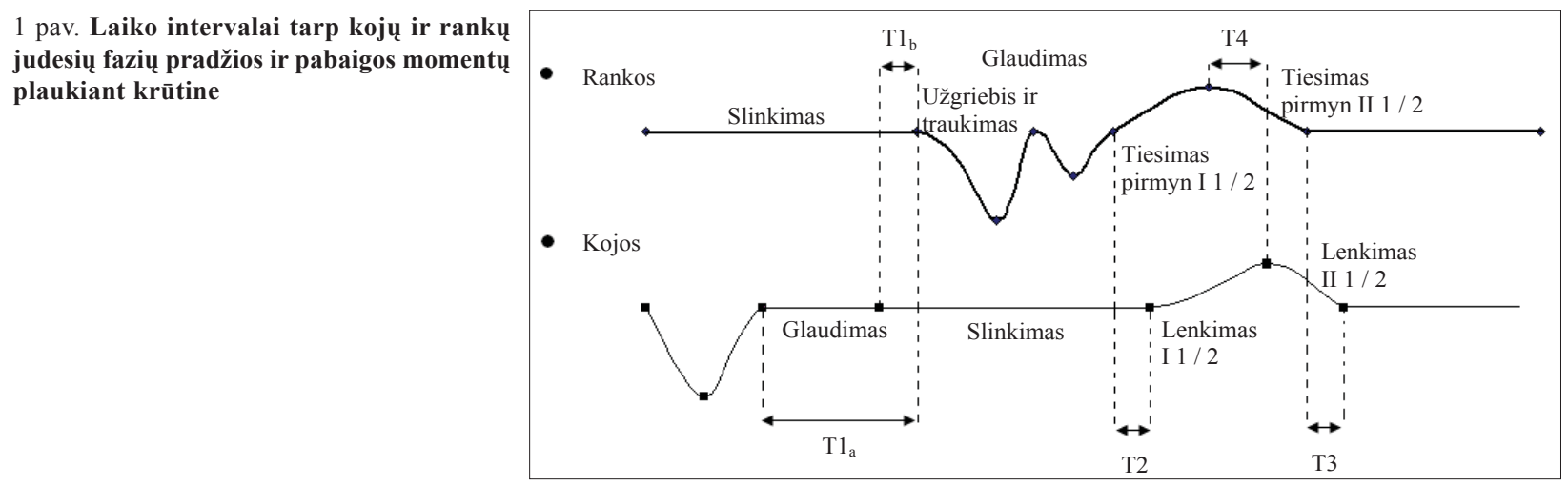


rankos ir kojos atlikdavo vienodą veiksmą. Šitaip buvo siekiama ịvertinti varomuju jëgų veikimo, pasirengimo (rankų tiesimo ir kojų lenkimo), slinkimo ir koju glaudimo naudingumą (veiksminguma) (Chollet et al., 2004). Grybšnio fazės trukmè pavadinta veiksmingumu dèl to, kad tuo metu rankos ir kojos atlieka tik vieną iš šių veiksmų: varomosios jègos sukūrimo, stabdymosi pasirengimo fazèje (rankų tiesimo, kojų lenkimo), neutralių veiksmu (slinkimo) arba aktyvios pasipriešinimo jègos sukūrimo (kojų glaudimo).

Varomuju jègu veikimo fazès naudingumas $\left(\mathrm{VAR}_{(\mathrm{ef})}\right)$ - tai laiko intervalas, kurio metu rankų ir kojų veiksmai sukuria traukio jègą. Pagal D. Chollet ir kt. (2004) jis apskaičiuotas susumavus koju atsispyrimo, rankų užgriebio ir suglaudimo fazių trukmę. Toks skaičiavimas tinkamas tik tuo atveju, jeigu šie veiksmai paeiliui eina vienas po kito. Jeigu $\mathrm{T} 1_{\mathrm{a}}>0$, užgriebis rankomis prasideda nepasibaigus atsispyrimui kojomis, o jei T2 ir / arba $\mathrm{T} 3<0$ - kojos pradedamos lenkti rankoms dar nesiglaudžiant. Skaičiuojant iš varomuju jègu veikimo fazès trukmès buvo atimta $\mathrm{T} 1_{\mathrm{a}}, \mathrm{T} 2 \mathrm{ir} / \mathrm{arba}$ T3 reikšmè.

Pasirengimo fazès naudingumas (rankų tiesimo ir kojų pritraukimo fazès) $\left(\mathrm{PAR}_{(\mathrm{ef})}\right)$ nèra rankų tiesimo ir kojų lenkimo fazių suma. Tai laiko intervalas, kurio metu rankos tiesiamos, o kojos lenkiamos. Jeigu T2 ir / arba T3 $<0$ - kojos pradedamos lenkti rankų dar neglaudžiant. Skaičiuojant iš pasirengimo fazès trukmès buvo atimta T2 ir / arba T3 reikšmè.

Slinkimo fazès naudingumas $\left(\operatorname{SLIN}_{(\mathrm{ef})}\right)$ - tai laiko intervalas nuo kojų glaudimo pabaigos iki užgriebio pradžios. Tačiau jeigu $\mathrm{T} 1_{\mathrm{b}}>0$, užgriebis rankomis prasideda tada, kai kojos dar neglaudžiamos, slinkimo fazè lygi nuliui.

Kojų suglaudimo fazès naudingumas $\left(\mathrm{KSUV}_{(\mathrm{ef})}\right)$ - tai laiko intervalas tarp visiško kojų ištiesimo per kelio sąnarị iki pẻdų glaudimo pabaigos momento. Tačiau jeigu $\mathrm{T} 1_{\mathrm{a}}>0$, užgriebis rankomis prasideda nepasibaigus atsispyrimui kojomis, koju glaudimo fazès naudingumas lygus nuliui.

Anksčiau išvardytos fazès buvo išreikštos procentais kojų ciklo trukmès atžvilgiu.

Matematinè statistika. Skaičiavimai atlikti naudojantis programos „Microsoft Excel“" statistiniu paketu Data Analysis. Apskaičiuotas aritmetinis vidurkis, standartinis nuokrypis. Aritmetinių vidurkiu skirtumo patikimumas nustatytas taikant Studento $t$ kriteriju. Vertinant patikimuma, imamas $\mathrm{p}<0,05$ ( $95 \%$ patikimumo) reikšmingumo lygmuo.

\section{REZULTATAI}

Plaukimo greitis, tempas ir grybšnio ilgis. Lietuvos ir Prancūzijos nacionalinès rinktinès narių plaukimo krūtine kinematiniai bei kojų ir rankų judesių derinimo rodikliai pateikti lentelèje. Žvaigždute pažymėti rodikliai, kurių skirtumas yra statistiškai patikimas $(*-p>0,05 ; * *-p<0,01)$. Duomenys rodo, kad plaukimo greitis, tempas ir grybšnio ilgis plaukiant 50 ir $100 \mathrm{~m}$ nuotolius patikimai nesiskyrè, tačiau galima pastebėti didesni Prancūzijos plaukiku grybšnio ilgị plaukiant ir lètai, ir greitai (žr. lent.).

Plaukimo greičio kitimas ciklo metu. Plaukimo greičio kitimo kreivès yra individualios, tačiau tam tikri ypatumai būdingi visiems Lietuvos plaukikams (žr. 2 B pav.). Lyginant kreivių formą matyti, kad Lietuvos plaukikų didžiausias momentinis greitis pasiekiamas ranku glaudimo pradžioje, Prancūzijos plaukiku — atsispyrimo kojomis pabaigoje. Tai rodo, kad Prancūzijos plaukikai puikiai išnaudoja kojų atsispyrimo jègą, nes šioje fazejje pasiekiamas didesnis greitis nei užgriebio ir traukimo metu. Lietuvos plaukikai nepakankamai veiksmingai užbaigia atsispyrimą, nes greitis pradeda mažèti dar jam nepasibaigus. Prancūzijos plaukikai nemažą greičio prieaugi pasiekia rankų suglaudimo fazejje, tuo tarpu Lietuvos plaukiku greitis tuo metu mažeja.

Plaukimo krūtine ciklo fazès. Plaukimo krūtine ciklo fazių santykinès trukmès analizè rodo, kad Lietuvos plaukikai patikimai daugiau $(\mathrm{p}<0,01)$ laiko skiria varomosios jègos sukūrimui rankomis (47\%, lyginant su 30\%), mažiau laiko rankų tiesimui pirmyn ir slinkimui. Skirtumas ypač išryškejja plaukiant 100 m nuotoli. Kojų judesiu fazių trukmè patikimai nesiskiria, išskyrus slinkimą ir kojų lenkimo pirmają dalị. Lietuvos plaukiku kojų lenkimas trunka patikimai ilgiau $(22,4 \pm 6,6$, lyginant su $13,3 \pm 3,6 \%)$, o slinkimas patikimai trumpiau, ypač plaukiant $50 \mathrm{~m}$ nuotoli $(23,1 \pm 19,0$, lyginant su $41,4 \pm 5,9 \%)$.

Kojų ir rankų judesių derinimas (koordinacija). Kojų ir ranku judesių koordinacija buvo vertinama apskaičiuojant laiko intervalus tarp atitinkamu ciklo fazių. Lietuvos plaukikų laiko intervalas nuo atsispyrimo kojomis pabaigos iki užgriebio rankomis pradžios $\left(\mathrm{T} 1_{\mathrm{a}}\right)$ bei laiko intervalas nuo kojų glaudimo pabaigos iki užgriebio pradžios $\left(\mathrm{T} 1_{\mathrm{b}}\right)$ buvo patikimai mažesnis $(\mathrm{p}<0,05)$ plaukiant 50 ir $100 \mathrm{~m}$ nuotolius. Lietuvos plaukikai, skirtingai nei Prancūzijos, pradeda lenkti kojas neužbaigę grybšnio rankomis (tai rodo Lietuvos plaukikų neigiama T2 


\begin{tabular}{|c|c|c|c|c|c|c|c|c|c|}
\hline \multirow{7}{*}{$\begin{array}{l}\text { Lentelè. Lietuvos } \\
\text { ir Prancūzijos na- } \\
\text { cionalinės rinkti- } \\
\text { nės narių plauki- } \\
\text { mo krūtine kine- } \\
\text { matiniai bei kojų } \\
\text { ir rankų judesių } \\
\text { derinimo rodi- } \\
\text { kliai, jų skirtumo } \\
\text { patikimumas }\end{array}$} & \multirow{3}{*}{ Rodikliai } & \multirow{2}{*}{\multicolumn{2}{|c|}{\begin{tabular}{|c|} 
Lietuvos plaukikai \\
$50 \mathrm{~m}$
\end{tabular}}} & \multirow{2}{*}{\multicolumn{2}{|c|}{\begin{tabular}{|c|} 
Chollet et al., 2004 \\
$50 \mathrm{~m}$
\end{tabular}}} & \multirow{2}{*}{\multicolumn{2}{|c|}{\begin{tabular}{|c|} 
Lietuvos plaukikai \\
$100 \mathrm{~m}$
\end{tabular}}} & \multirow{2}{*}{\multicolumn{2}{|c|}{$\begin{array}{c}\text { Chollet et al., 2004 } \\
100 \mathrm{~m}\end{array}$}} \\
\hline & & & & & & & & & \\
\hline & & $\mathbf{x}$ & б & $\mathbf{x}$ & б & $\mathbf{x}$ & б & $\mathbf{x}$ & б \\
\hline & Greitis, $\mathrm{m} / \mathrm{s}$ & 1,42 & 0,48 & 1,37 & 0,13 & 1,35 & 0,07 & 1,33 & 0,12 \\
\hline & Tempas, ciklai / min & 44,37 & 0,84 & 47,35 & 8,00 & 35,80 & 2,61 & 39,29 & 6,40 \\
\hline & Grybšnio ilgis, $\mathrm{m}$ & 1,53 & 0,58 & 1,70 & 0,23 & 1,75 & 0,14 & 2,00 & 0,30 \\
\hline & $\begin{array}{l}\text { Varomosios jëgos } \\
\text { sukūrimas rankomis, \% }\end{array}$ & $47,26 * *$ & 8,81 & 29,60 & 5,70 & $45,21 * *$ & 3,91 & 27,30 & 6,00 \\
\hline \multirow{21}{*}{$\begin{array}{l}\text { Pastaba. } x \text { - ari- } \\
\text { tmetinis vidurkis; } \\
6 \text { - vidutinis stan- } \\
\text { dartinis nuokrypis; } \\
*-p>0,05 \\
* *-p<0,01\end{array}$} & Užgriebis, \% & 30,19 & 5,96 & 22,90 & 6,20 & $27,29 *$ & 5,49 & 20,50 & 4,40 \\
\hline & Rankų glaudimas, \% & $16,49 * *$ & 2,92 & 6,60 & 1,60 & $13,21 * *$ & 2,36 & 6,80 & 2,80 \\
\hline & Slinkimas, \% & 36,20 & 7,09 & 42,50 & 7,80 & $34,76^{*}$ & 10,97 & 48,12 & 7,80 \\
\hline & Rankų tiesimas pirmyn, \% & $17,96 * *$ & 2,50 & 27,70 & 5,40 & $16,32 * *$ & 2,82 & 24,50 & 4,70 \\
\hline & Pirmoji dalis, \% & 8,70 & 3,76 & 14,10 & 4,50 & 8,84 & 1,83 & 12,10 & 3,70 \\
\hline & Antroji dalis, \% & 10,23 & 4,41 & 13,70 & 4,80 & 7,73 & 2,23 & 12,50 & 4,50 \\
\hline & Atsispyrimas, $\%$ & 19,58 & 7,82 & 17,60 & 4,20 & 19,10 & 1,85 & 16,50 & 5,30 \\
\hline & Kojų glaudimas, \% & 10,23 & 4,41 & 11,50 & 4,10 & 10,86 & 2,25 & 10,90 & 3,80 \\
\hline & Slinkimas, $\%$ & $23,10 *$ & 19,00 & 41,40 & 5,90 & 36,31 & 10,21 & 46,20 & 6,80 \\
\hline & Kojų lenkimas, \% & 32,85 & 16,42 & 29,40 & 6,30 & 32,83 & 8,17 & 26,30 & 4,60 \\
\hline & Pirmoji dalis, $\%$ & 21,19 & 8,50 & 14,70 & 4,00 & $22,42 * *$ & 6,65 & 13,30 & 3,60 \\
\hline & Antroji dalis, \% & 11,65 & 3,35 & 14,60 & 3,70 & 11,64 & 3,06 & 12,90 & 2,90 \\
\hline & $\mathrm{T} 1_{\mathrm{a}}$ & $-10,17^{*}$ & 10,67 & $-22,06$ & 6,00 & $-18,49^{*}$ & 7,90 & $-29,30$ & 6,30 \\
\hline & $\mathrm{T} 1_{\mathrm{b}}$ & $1,25^{*}$ & 12,18 & $-10,40$ & 7,80 & $-7,97 *$ & 8,72 & $-18,40$ & 7,40 \\
\hline & $\mathrm{T} 2$ & & 9,03 & 2,30 & 1,80 & & 6,84 & 1,90 & 2,90 \\
\hline & T3 & 3,82 & 3,22 & 4,10 & 6,30 & 4,67 & 3,21 & 3,70 & 5,50 \\
\hline & $\mathrm{T} 4$ & $-1,11$ & 2,79 & 3,10 & 5,60 & 0,63 & 1,84 & 3,30 & 4,20 \\
\hline & $\mathrm{VAR}_{(\mathrm{ef})}$ & 54,10 & 7,77 & 45,10 & 7,40 & 48,61 & 8,27 & 42,10 & 8,20 \\
\hline & $\mathrm{PAR}_{(\mathrm{ef})}$ & $22,06 * *$ & 3,01 & 31,60 & 5,90 & $21,22 *$ & 2,93 & 28,30 & 5,10 \\
\hline & $\operatorname{SLIN}_{(\mathrm{ef})}$ & $-1,25^{*}$ & 12,18 & 10,40 & 7,70 & 7,97 & 8,72 & 17,20 & 9,10 \\
\hline & $\mathrm{KSUV}_{(\mathrm{ef})}$ & 11,42 & 2,29 & 11,50 & 4,10 & 10,52 & 2,34 & 10,90 & 3,80 \\
\hline
\end{tabular}

reikšmė (žr. lent.)). Lietuvos ir Prancūzijos plaukiku kojų lenkimas baigiasi šiek tiek vẻliau nei rankos tiesiamos pirmyn - T3 ir T4 patikimai nesiskiria.

Fazių naudingumas (veiksmingumas). Varomujų jėgų veikimo fazès naudingumas $\left(\mathrm{VAR}_{(\mathrm{ef})}\right)$, išreikštas santykine trukme, patikimai nesiskyrè, nors galima pastebėti, kad Lietuvos plaukikų varomaja jèga sukuriančios fazès santykiškai trunka ilgiau. Patikimas skirtumas nustatytas tarp pasirengimo $\left(\operatorname{PAR}_{(\mathrm{ef})}\right)$ ir slinkimo fazių $\left(\mathrm{SLIN}_{(\mathrm{ef})}\right)$ naudingumo. Prancūzijos plaukikų rezultatai plaukiant lètai ir greitai $\operatorname{PAR}_{(\mathrm{ef})}$ bei plaukiant greitai $\operatorname{SLIN}_{(\mathrm{ef})}$ patikimai didesni.

\section{REZULTATŲ APTARIMAS}

Norint nustatyti biomechaninius veiksnius, ribojančius Lietuvos plaukikų greiti plaukiant krūtine, buvo išanalizuoti literatūroje pateikti ivvairių šalių nacionalinio ir tarptautinio lygio plaukiku technikos rodikliai. Lietuvos plaukiku meistriškumas, kurị ịvertinome apskaičiavę jų 50 ir $100 \mathrm{~m}$ plaukimo krūtine rezultatu procentinę reikšmę nuo pasaulio rekordu, labiausiai atitiko D. Chollet ir kt. (2004) tirtų Prancūzijos plaukikų meistriškumo lygit. Kadangi Lietuvos ir Prancūzijos plaukikų plaukimo greitis, tempas ir grybšnio ilgis patikimai nesiskyrè, galima teigti, kad nustatytas momentinio greičio kitimo kreivių skirtumas parodo Lietuvos plaukikų technikos ypatumus.

Lietuvos plaukikų didžiausias momentinis greitis pasiekiamas ranku glaudimo pradžioje, Prancūzijos plaukiku — atsispyrimo kojomis pabaigoje. Kitu tyrejju pateiktose greičio kitimo kreivèse momentinis greitis kojų tiesimo pabaigoje yra lygus arba didesnis už greiti, pasiekiamą užgriebio bei pasitraukimo fazejje ir gali siekti $2,2-2,5 \mathrm{~m} / \mathrm{s}$ (Craig et al., 2006; Leblank et al., 2007). Lietuvos plaukikų didžiausias momentinis greitis kojų tiesimo metu siekia 1,5 m/s. Tai rodo, kad Lietuvos plaukikų kojų atsispyrimo jèga yra per maža arba ji panaudojama neveiksmingai, ypač atsispyrimo pabaigoje, nes greitis pradeda mažèti dar nepasibaigus atsispyrimui. Kojų tiesimo trukmè nepriklauso nuo plaukikų meistriškumo (Leblanc et al., 2005), tačiau, B. E. Ungerechts (1988) teigimu, kojų tiesimo 


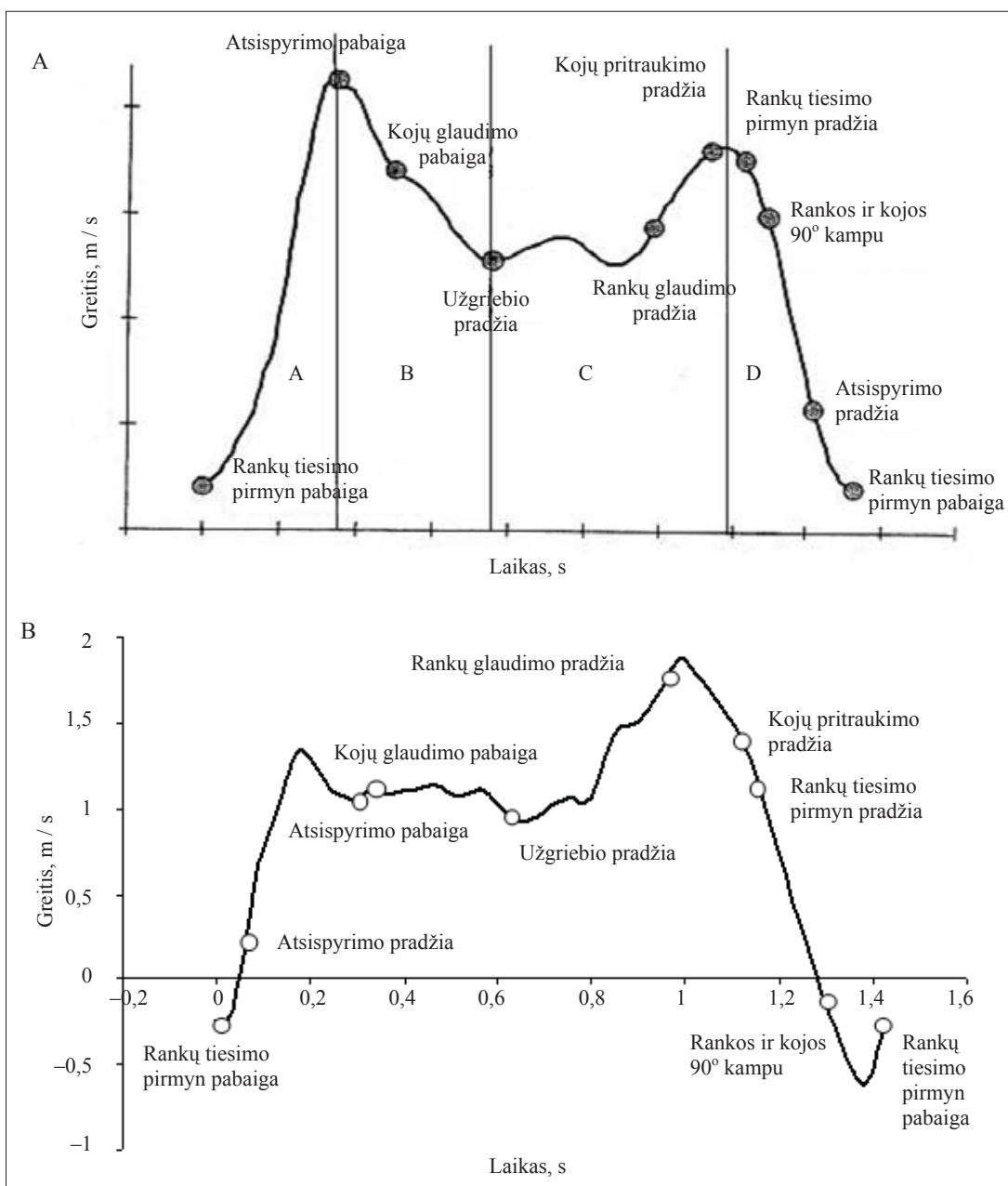

2 pav. Plaukimo momentinio greičio kaita ciklo metu bei fazių pradžios ir pabaigos momentai

Pastaba. A - modifikuota Prancūzijos plaukikų greičio kreivè (Chollet et al., 2004). $\mathrm{B}$ - Lietuvos plaukiku greičio kreivè.

trukmę galima sieti su atsispyrimo jègos veikimo trukme. Lietuvos plaukiku kojų tiesimo santykinè trukmè nesiskiria nuo kitu plaukikų, tačiau greitis atsispyrimo metu yra daug mažesnis. Atsispyrimo jègos mažą veiksmingumą gali lemti blogas viršutinès kūno dalies aptakumas atsispyrimo metu, per anksti keliama galva, per žemai nuleistos kojos.

Prancūzijos plaukikai nemažą greičio prieaugi pasiekia rankų suglaudimo fazeje, o Lietuvos plaukiku greitis tuo metu mažéja. D. Chollet ir kt. (2004), A. B. Craig ir kt. (1988), P. M. Soares ir kt. (1999), H. Leblanc ir kt. $(2005,2007)$, remdamiesi greičio kitimo kreive, išskyrè keturias plaukimo krūtine ciklo fazes (2 A pav.): A. Greičio didejjimas - varomosios jègos sukūrimas tiesiant kojas; B. Greičio mažejimas - kojų glaudimas, slinkimas iki užgriebio rankomis pradžios; C. Greičio didèjimas - varomosios jègos sukūrimas užgriebio, traukimo ir rankų glaudimo metu; D. Greičio mažéjimas — kojų lenkimas ir rankų tiesimas. Išskirtas fazes galima sugrupuoti kaip darbines (A ir C fazès) ir parengiamąsias (B ir D fazès). D. Chollet ir kt. (2004), H. Leblanc ir kt. $(2005,2007)$ ranku glaudimą priskiria prie darbinès fazès, nes jos metu sukuriama varomoji jèga — kūnas juda greitejančiai. C. Tourny ir kt. (1992) teigia, kad ranku glaudimo metu varomosios jègos veiksmingumas pasireiškia labiausiai. Nors Lietuvos plaukikų rankų darbinè fazé santykiškai trunka ilgiau (ypač rankų glaudimas: $16,49 \%$, palyginti su $6,60 \%$ plaukiant 50 m nuotoli, ir $13,21 \%$, palyginti su $6,80 \%$ plaukiant $100 \mathrm{~m}$ nuotoli), greičio kitimo kreivè rodo nepakankamą rankų glaudimo veiksminguma, kurio priežastimi gali būti blogas kūno aptakumas arba bloga ranku glaudimo technika, dèl to sukuriama maža varomoji jèga. H. Leblanc ir kt. (2005) nustatè, kad mažesnio meistriškumo plaukikų rankų glaudimo trukmė yra didesné, ir tai siejo su dažnai pasitaikančia technikos klaida - per dideliu ranku pasukimu atgal, kada alkūnès juda atgal, o plaštakos leidžiasi žemyn. Tai padidina vandens pasipriešinimą ir laiko sąnaudas. Norint padidinti šios fazès veiksminguma, alkūnes būtina energingai spausti žemyn, o ne paprastai nuleisti priešais krūtinę (Maglischo, 1993). Anot L. J. D'Acquisto ir kt. (1988), elito plaukikai išsiskiria tuo, kad sugaišdami tiek pat laiko atliekant veiksmus, sukuriančius varomąsias jègas, ciklo metu geba nuplaukti didesni atstumą. Lietuvos plaukiku varomają jègą sukuriančios fazès santykiškai trunka ilgiau, o grybšnio ilgis yra mažesnis. 
Judesių derinimo analizè parodé, kad Lietuvos plaukikai, skirtingai nei Prancūzijos, pradeda lenkti kojas neužbaigę grybšnio rankomis (tai rodo Lietuvos plaukikų neigiama T2 reikšmė (žr. lent.)). Literatūros duomenimis, toks judesių derinimas būdingas didelio meistriškumo plaukikams įveikiant trumpuosius nuotolius (Chollet et al., 2004), tačiau jų sukurta varomoji jèga rankų suglaudimo metu, matyt, yra didesnè už hidrodinaminę pasipriešinimo jègą, kuri atsiranda lenkiant kojas.

Lietuvos plaukikų kojų lenkimas (pirmoji dalis) trunka patikimai ilgiau $(22,42 \pm 6,65$, lyginant su $13,3 \pm 3,6 \%$ ), o slinkimas patikimai trumpiau $(23,1 \pm 19$, lyginant su 41,4 $\pm 5,9 \%)$. Judesių derinimo analizè parode, kad Lietuvos plaukikai trumpiau slenka, nes daug mažesnis laiko intervalas tarp koju tiesimo pabaigos ir rankų užgriebio pradžios $\left(\mathrm{T}_{\mathrm{a}}\right)$. Plaukiant $50 \mathrm{~m}$ nuotoli, daugeliu atvejų užgriebis prasideda neglaudžiant kojų $(\mathrm{T} 1 \mathrm{~b}<0)$. Tokia judesiu koordinacija būdinga didelio meistriškumo plaukikams (Leblanc et al., 2005), tačiau jie, skirtingai nuo mažesnio meistriškumo plaukiku, plaukia didesniu grybšniu. L. J. D'Acquisto ir kt. (1988) nustate pati- kimą koreliacini ryši tarp parengiamujų fazių trukmès ir atstumo, nuplaukto jų metu. Didelio meistriškumo plaukikai geba sumažinti vandens pasipriešinima užimdami aptakesnę padètį šių fazių metu. Tai glaudžiai susiję su plaukimo ekonomiškumu (Vilas-Boas, 1996). H. Leblanc ir kt. (2005) duomenimis, didelio meistriškumo plaukikų slinkimo fazès naudingumas, plaukiant $1,49 \mathrm{~m} / \mathrm{s}$ greičiu, siekia 7,95\%, Lietuvos plaukiku, plaukiant $1,42 \mathrm{~m} / \mathrm{s}$ greičiu, $-1,25 \%$. Lietuvos plaukikai santykiškai ilgiau laiko užima ne tokią aptakią padèti, todèl santykiškai ilgiau juos veikia didesnè kūną stabdanti hidrodinaminè jèga. Tai dar kartą patvirtina mūsų teigini, kad Lietuvos plaukikų plaukimo krūtine technika yra nepakankamai veiksminga ir ekonomiška.

\section{IŠVADOS}

Lietuvos plaukikai nepakankamai veiksmingai išnaudoją darbines fazes - atsispyrimą kojomis ir rankų glaudimą. Pasirengimo fazèse kūnas ilgiau užima neaptakią padètí nei aptakią, dèl to didejja greičio svyravimas ciklo metu.

\section{LITERATŪRA}

Chollet, D., Boulesteix, L. (2001). Evolution of the butterfly coordination in relation to velocity and skill levels of swimmers. In R. H. Sanders (Ed.), XIX International Symposium on Biomechanics in Sports (pp. 22-26). University of San Francisco.

Chollet, D., Seifert, L., Leblanc, H., Boulesteix, L., Carter, M. (2004). Evaluation of arm-leg coordination in flat breaststroke. International Journal of Sports Medicine, 25 (7), 486-495.

Chollet, D., Tourny, C., Gleizes, F. (1999). Evolution of co-ordination in flat breaststroke in relation to velocity. Biomechanics and Medicine in Swimming VIII (pp. 2932). Jyvaskyla: University of Jyvaskyla.

Colman, V., Persyn, U., Daly, D., Stijnen, V. (1998). A comparison of the intra-cyclic velocity variation in breaststroke swimmers with flat and undulating styles. Journal of Sports Sciences, 16 (7), 653-665.

Costill, D. L, Lee, G., D’Acquisto, L. J. (1987). Videocomputer assisted analysis of swimming technique. Journal of Swimming Research, 3, 5-9.

Craig, A. B., Boomer, W. L., Skehan, P. L. (1988). Patterns of velocity in competitive breaststroke, in Swimming V. In B. E. Ungerechts, K. Vilke, K. Reischle (Eds.), Swimming Science V (pp. 73-77). Illinois: Human Kinetics Publishers.

Craig, A. B., Termin, B., Pendergast, D. R. (2006). Simultaneous recordings of velocity and video during swimming Portuguese Journal of Sport Sciences, 6 (2), 32-35.

D’Acquisto, L. J., Costill, D. L., Gehlsen, G. M., Wong-Tai Young, Lee, G. (1988). Breaststroke economy, skill, and performance. Journal of Swimming Research, 4 (2), 9-13.

Kolmogorov, S. V., Rumyantseva, O. A., Gordon, B. J., Cappaert, J. M. (1997). Hydrodynamic characteristics of competitive swimmers of different genders and performance levels. Journal of Applied Biomechanics, 13 (1), 88-97.

Leblanc, H., Seifert, L., Baudry, L., Chollet, D. (2005). Arm-leg coordination in flat breaststroke: A comparative study between elite and non-elite swimmers. International Journal of Sports Medicine, 26 (9), 787-797.

Leblanc, H., Seifert, L., Tourny-Chollet, C., Chollet, D. (2007). Intra-cyclic distance per stroke phase, velocity fluctuations and acceleration time ratio of a breaststroker's hip: A comparison between elite and nonelite swimmers at different race paces. International Journal of Sports Medicine, 28 (2), 140-147.

Magel, J. R. (1970). Propelling force measured during tethered swimming ir the four competetive swimming styles. Research Quarterly, 41 (1), 68-74.

Maglischo, E. W. (1993). Swimming Even Faster. Mountain View: Mayfield Publishing.

Mc Elroy, K., Blanksby, B. (1976). Intra-cycle velocity fluctuations of highly skilled breaststroke swimmers. Physical Education and Recreation. Australian Journal of Primary Health, 71, 25-34.

Nemessuri, M., Vaday M. (1971). Breaststroke motor pattern. Swimming Science I (pp. 161-165). Brussels: Universite libre de Bruxelles.

Sanders, R. H. (1996). Breaststroke technique variations among New Zealand Pan Pacific Squad swimmers. In J. P. Troup, A. P. Hollander, D. Strasse, S. W. Trappe, J. M. Cappaert, T. A. Trappe (Eds.), Biomechanics and Medicine in Swimming VII. Selected papers from the VII International Symposium on Biomechanics and Medicine in Swimming (pp. 64-69). Atlanta, GA: E\&F.N. Spon.

Silva, A., Colman, V., Soons, B., Alves, F., Persyn, U. (2003). 
Performance relevant time-space variables for breaststroke: Sex differentiation and whole group. In J. C. Chatard (Ed.), Biomechanics and Medicine in Swimming 9 (pp. 179-183). Publications del'Université de St. Etienne.

Soares, P. M., Sousa, F., Vilas-Boas, J. P. (1999). Differences in breaststroke synchronization induced by different race velocities. In K. L. Keskinen, P. V. Komi, A. P. Hollander, Swimming Science VIII (pp. 53-57). Jyvaskyla: University of Jyvaskyla.

Tourny, C., Chollet, D., Micallef, J. P., Macabies, J. (1992).

Comparative analysis of studies of speed variations with in a breaststroke cycle. Biomechanics and Medicine in Swimming VI (pp. 161-166). London: E \& Spon.

Ungerechts, B. E. (1988). The relation of peak body acceleration to phases of movements in swimming. In B. E. Ungerechts, K. Wilke, K. Reischle (Eds.), Swimming Science $V$ Human Kinetics (pp. 61-68). Champaign.

Vilas-Boas, J. P. (1996). Speed fluctuations and energy cost of different breaststroke techniques. In J. P. Troup, A. P. Hollander, D. Strass, S. W. Trappe, J. M. Cappaert, T. A. Trappe (Eds), Swimming Science VII (pp. 167-171). London: E \& Spon.

\title{
INTRA-CYCLIC VELOCITY FLUCTUATION AND ARM-LEG COORDINATION OF THE WORLD AND LITHUANIAN INTERNATIONAL LEVEL BREASTSTROKE SWIMMERS WITH FLAT STYLE
}

\author{
Danguolė Satkunskienė, Valentina Skyrienė \\ Lithuanian Academy of Physical Education, Kaunas, Lithuania
}

\begin{abstract}
The purpose of this investigation was to carry out comparison of intra-cyclic velocity fluctuation and armleg coordination among Lithuanian and World international level breaststroke swimmers to identify the technical factors limiting swimming velocity of Lithuanian swimmers.

Four Lithuanian male swimmers whose expertise expressed in percentage of the world record (\% of WR) for the $100 \mathrm{~m}$ breaststroke on the average reached $92.9 \pm 4.7 \%$ and nine French swimmers $(91.4 \pm 2.4 \%$ of WR) (Chollet et al., 2004) were included in the analysis.

Lithuanian swimmers were simulated the 50 and $100 \mathrm{~m}$ paces swims starting in the water in a $25-\mathrm{m}$ pool. All the swimmers were filmed from side view underwater with one video camera moving parallel to the swimmer on a tracking system and one panning video camera above water. Moments defining begin - end phases were determined from video analysis using a $50 \mathrm{~Hz}$ video player of SIMI Motion 2D software. In addition, a body landmark on the pelvis was digitized. Dropped scale lines suspended from the lane cable were used for calibration. The intra-cycle pelvis velocity was obtained by video analysis. The breaststroke cycle was divided into five arm and leg phases. The duration of each phase was expressed as a proportion of the whole stroke cycle. Arm-leg coordination was determined by measurement of the time gaps between the different stroke phases of each pair of motor limbs (Chollet et al., 2004). Based on time gaps effective glide, effective propulsion, effective leg insweep and effective recovery were used to identify the different stroke phases on the body. Average swimming velocity was calculated from the video recording over a $10-\mathrm{m}$ distance. The stroke length was calculated from the average speed and stroke rate.

There were no significant differences between Lithuanian and World international level swimmers' swimming velocity, stroke rate and stroke length. The analysis of time velocity curves showed that the maximum velocity peaks for Lithuanian swimmers corresponding to the end of arm outsweep and than during arm insweep velocity was decreased. The first increase in velocity associated with the leg extension was markedly, less then increase occurred during arm propulsion phase and the velocity peak occurred before the end of leg extension.

Lithuanian swimmers had a longer duration of the upper limbs propulsion phase ( $47 \mathrm{vs} .30 \%$ on average) and the first part of leg recovery ( 22.4 vs. $13.3 \%$ ), a shorter duration of the arm recovery ( $17 \mathrm{vs.} 26 \%$ on average), arm gliding especially by swimming $100 \mathrm{~m}$ pace (34.76 vs. $48.12 \%$ ) and leg gliding especially by swimming $50 \mathrm{~m}$ pace (23.1 vs. $41.4 \%$ ); shorter $\mathrm{T} 1_{\mathrm{a}}$ and $\mathrm{T} 1_{\mathrm{b}}$ time gap (measuring the glide effect) and negative $\mathrm{T} 2$ time gap what meant that the beginning of leg recovery overlapped the end of arm propulsion.

It was concluded that the efficiency of propulsive and non propulsive phases of Lithuanian elite breaststroke swimmers were less than that of world elite swimmers by swimming at the same speed.
\end{abstract}

Keywords: breaststroke, coordination, intra-cyclic velocity.

Gauta 2008 m. rugsèjo $30 \mathrm{~d}$.

Received on September 30, 2008

Priimta 2008 m. gruodžio $9 \mathrm{~d}$.

Accepted on December 9, 2008
Valentina Skyrienè

Lietuvos kūno kultūros akademija

(Lithuanian Academy of Physical Education)

Sporto g. 6, LT-44221 Kaunas

Lietuva (Lithuania)

Tel +370 37302666

E-mail v.skyriene@1kka.lt 